\title{
Modelling and Analysis Fuel Cell with Battery Storage Microgrid System Based on Green Energy
}

\author{
Alias Khamis*, Mohd Ruddin Ab. Ghani, Chin Kim Gan, Hairol Nizam Mohd Shah, \\ Mohd Zamzuri Ab. Rashid and Mohd Khairi Mohd Zambri \\ Faculty of Electrical Engineering, Univerisiti Teknikal Malaysia Melaka; alias@utem.edu.my, dpdruddin@utem.edu.my, \\ ckgan@utem.edu.my,hnizam@utem.edu.my,zamzuri@utem.edu.my,khairi_z@utem.edu.my
}

\begin{abstract}
Objectives: This study is aimed at analyzing the characteristics of an $11 \mathrm{kV}$ microgrid system when connected to a combination source of fuel cell and battery storage. Methods/Statistical Analysis: To do so, Matlab Simulink software was used as simulation platform. Three types of connection were simulated which are first; fuel cell to grid, second; battery storage to grid and lastly; combination of fuel cell and battery storage to grid $^{1}$. Findings: For each connection type, parameters such voltage, current, active power and reactive power are recorded when the grid is either in connected or disconnected mode. Simulation results have shown positive values of active power and reactive power which flows from the source to the grid side in both modes. Application/Improvements: This implies that the combination of fuel cell and battery storage is a reliable source for a particular constructed microgrid system to be successful. If implemented in real application, the suggested microgrid system will be a dependable alternative to supply electricity to rural areas which are too remote and unfeasible to be connected to a conventional grid system.
\end{abstract}

Keywords: Battery Storage, Fuel Cell, Microgrid, Matlab Simulink, Renewable Energy

\section{Introduction}

\subsection{Microgrid}

MG is systems that connect houses, factories and other buildings to power central sources ${ }^{2}$. A normal grid or traditional grid will connect to the houses, factories or other building but when there is maintenance works need to be done, all of the connected building will be cut off from receiving the supply. This is a situation that can be corrected by connecting the building using MG.

\subsubsection{Microgrid Configurations}

MG is systems that have low voltage or medium voltage distribution network that surround by DG, energy storage systems and loads, operating as a single controllable system $^{3}$. Basically MG can be power on in case of emergency such as lightning strike or storms, without disturbing the supply to the loads. This is due to the connection of the load with the DG. DG is a used for capacity support, voltage support and regulation, and line loss reduction ${ }^{3}$.

DG usually made of many new technologies such as fuel cell, photo-voltaic systems and several kinds of wind turbines. This DG will be the backup whenever the load is cut off from the main grid as shown in Figure 1.

\subsubsection{Microgrid Operation}

Figure 2 shows the MG operation. In the figure, it shows a group of feeders connecting to each other. There is a single point of connection to the main distribution utility called point of common coupling (PCC). PCC is the point in the electric circuit where a MG is connected to a main grid $^{4}$. There is also a point called SD that is Separation Device which can disconnect MG immediately whenever fault happens in the distribution grid. The figure below shows in feeders 1 and 2, it has local generation which is require because it have sensitive loads. There is also loads 


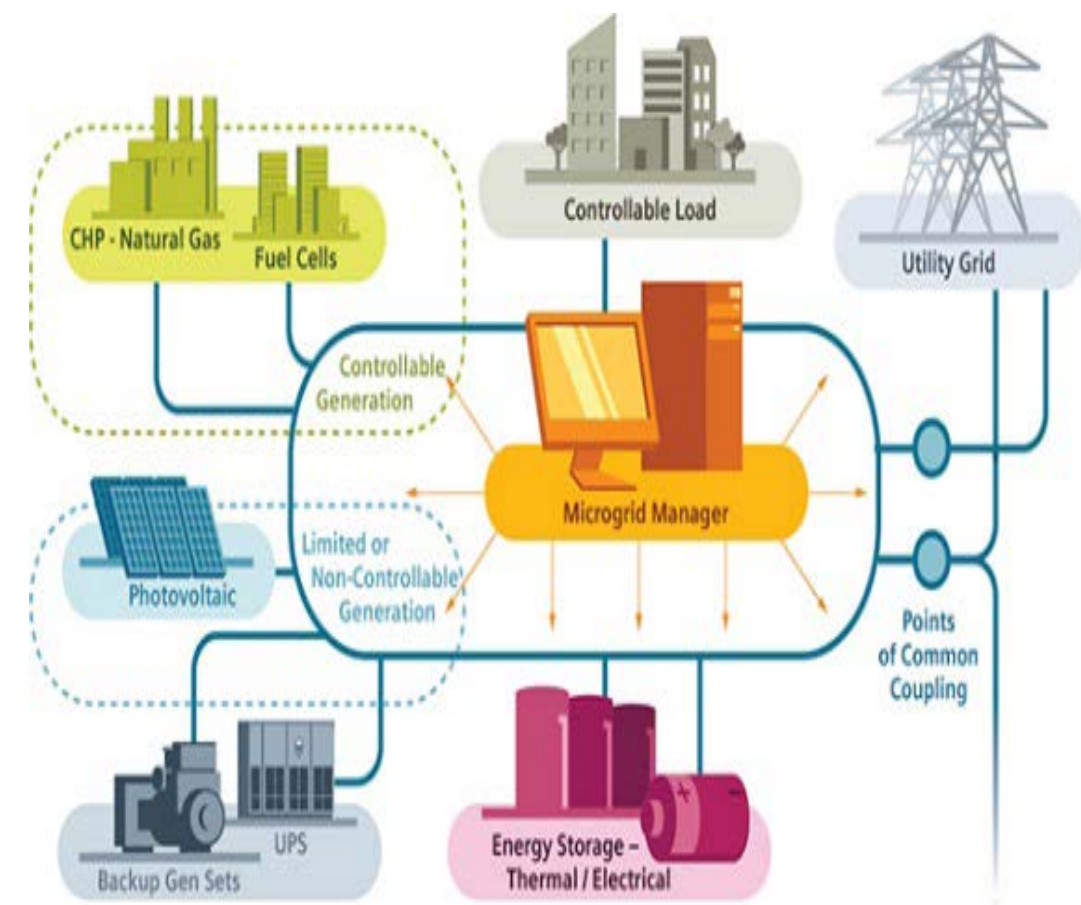

Figure 1. A microgrid overview ${ }^{3}$.

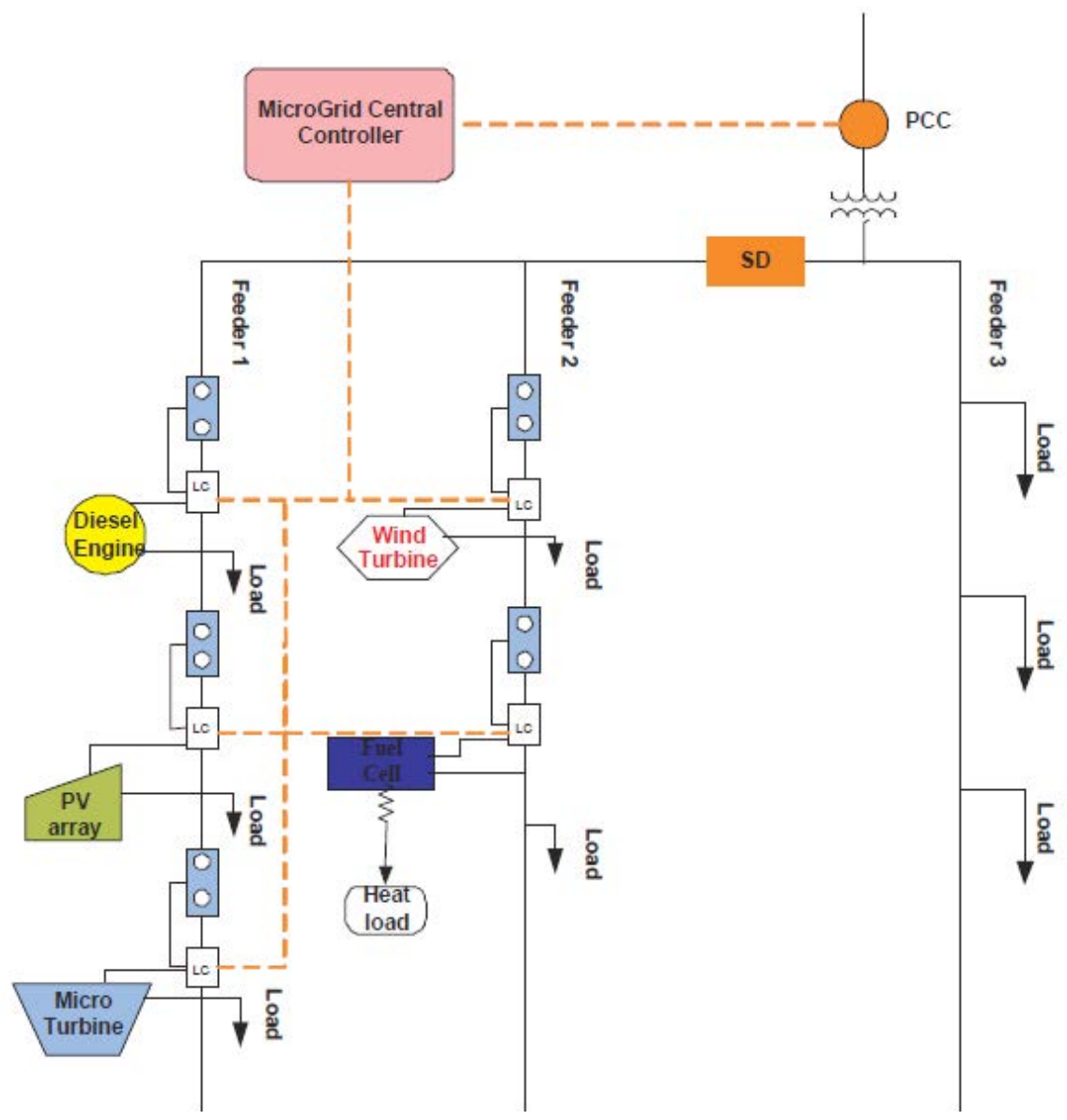

Figure 2. Operation of microgrid ${ }^{4}$. 
that do not have any local generation that is traditional load, connected to Feeder $3^{4}$.

\subsection{Fuel Cell}

Fuel cell is a device that converts chemical energy from fuel into electricity. Electricity was form through a chemical reaction of positive charged hydrogen ions with oxygen or other oxidizing agent ${ }^{5}$. Fuel cells was first invented in 1838 , but, the world only know its existence until more than a century later through NASA space programs which to generate power for satellites and space capsules. Ever since then, fuel cells were broadly used in many applications which focused as a primary and backup power for industries, residential and commercial buildings. The ability to be installed in remote and inaccessible areas makes it possible for the used in powering vehicles such as forklift, buses, boats, submarines, automobiles and motorcycles.

\subsubsection{Fuel Cell Modelling}

Fuel cells have variety of different types as shown in Figure 3. Each of it consist of an anode, a cathode and electrolyte which allow positive charged hydrogen ions to move between the two sides of fuel cell. To generate positive hydrogen ions and electrons, each anode and cathode contains catalysts which caused the fuel to oxidize. After

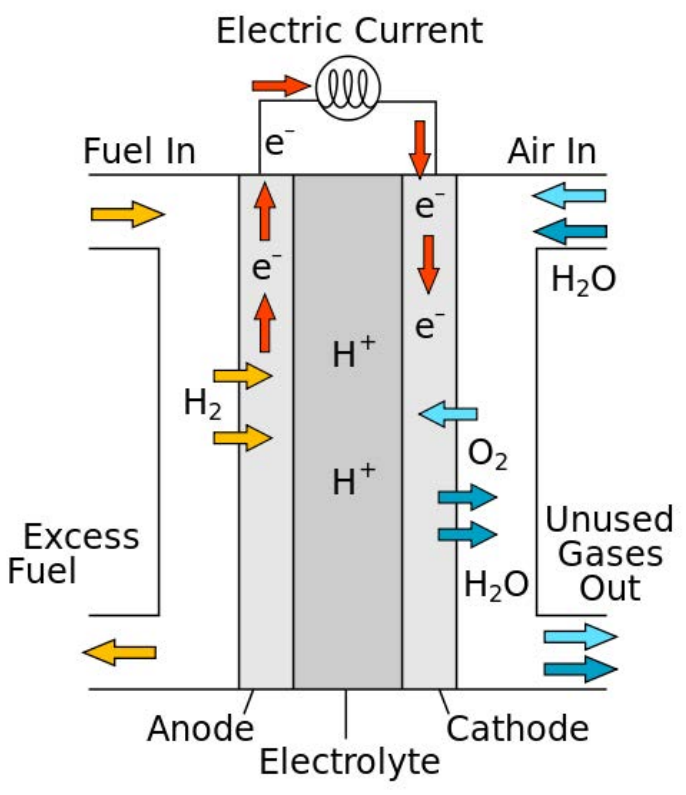

Figure 3. Construction of fuel cell ${ }^{6}$. the oxidation reactions, the hydrogen ions are drawn to the electrolyte. Simultaneously, through an external circuit, electrons are also drawn from the anode to the cathode. This helps produced direct current electricity. Hydrogen ion, electrons, and oxygen react with each other at the cathode to form water 6 .

The two half reactions occur in the fuel cell are:

At anode:

$$
\mathrm{H}_{2}(\mathrm{~g}) \rightarrow 2 \mathrm{H}^{++} 2 \mathrm{e}^{-}
$$

At cathode:

$$
\frac{1}{2} \mathrm{O}_{2}(\mathrm{~g})+2 \mathrm{H}^{+}+2 \mathrm{e}^{-} \rightarrow \mathrm{H}_{2} \mathrm{O}
$$

Overall reaction:

$$
\mathrm{H}_{2}(\mathrm{~g})+\frac{1}{2} \mathrm{O}_{2}(\mathrm{~g}) \rightarrow \mathrm{H}_{2} \mathrm{O}
$$

\subsubsection{Fuel Cell Characteristic}

There are many types of fuel cell line such as Alkaline Fuel Cell (AFC), Proton Exchange Membrane Fuel Cell (PEMFC) and Phosphoric Acid Fuel Cell (PAFC). These fuel cells generate direct current. According to the power rating, there are numerous way of a fuel cells was chosen. $1 \mathrm{KW}$ fuel cells has the output voltage range $25-50 \mathrm{~V}$ while $30 \mathrm{KW}$ and above of fuel cells can have output voltage range $200-400 \mathrm{~V}$. Fuel cells are in a development stage as stated in ${ }^{7}$. Below are the assumptions about the operating characteristics:

1. Fuel cell with type of PEMFEC has low temperature and have partial oxidation, it takes minor time to start-up while a high temperature fuel cell will take 3 to 4 hours to start up. This show that fuel cell with low temperature is more suitable for start-stop operation since the start up time takes small amount of time.

2. Although fuel cell can do nearly instant load changes, it has a limit in the fuel processing system which has a certain time of lag due to the chemical reactions occur.

3. As the numbers of moving parts are low, fuel cells have the potential for high in reliability. Life length of fuel cells is given as $40000 \mathrm{~h}$ for the stack and at least twice the number of hours for the system. 


\subsection{Battery Storage}

In recent years, due to large integration of Renewable Energy Sources like microturbine and fuel cell unit into the MG, the supplication of Battery Storage (BS) has surge greatly. The BS has considerable interest and advantages in the MG-based applications such as short term power supply, power quality improvement, facilitating integration of Renewable Energy Sources and providing necessary support to the primary activities service ${ }^{8}$.

\subsubsection{Operation of Battery}

From the article in ${ }^{9}$, it said that the battery is initially charged with the help of DG and Battery Management System (BMS). The article explained the operation of the battery storage by using Photovoltaic (PV), one of type of DG, as the source for charging. In the Figure 4 shown BMS is used for observing the charging and discharging level of the battery. Therefore, the battery span time can be lengthening. By using three levels of universal bridge inverter, a power electronics converter interfaces the energy storage unit with MG and the communication line between the Microgrid Central Controller (MGCC) and Battery Energy Storage System (BESS) management. The MGCC is also one of the observing blocks, which monitors the grid voltage and frequency. The power generated by PV system is not sufficient to meet the local load means the load will import the power from the MG and the battery is charged because the inverter act as converter. If the power generated is in excess, PV system export the power to the MG. If the grid voltage is in abnormal condition, local load is disconnected from the MG and it operates as island mode.

\subsubsection{Types of Battery Storage}

The first battery in market was the flooded lead-acid battery which was used for establish, centralized applications. The valve-regulated lead acid (VRLA) battery is the current commercially convenient option. Other lithiumbased batteries are under progression ${ }^{10}$. Batteries are produced in a wide assortment of capacities ranging from less than 100watts to modular configurations of several megawatts.

\subsubsection{Lead-Acid Battery}

Lead Acid batteries are barely economic but they have big space and maintenance necessity. The usage of battery below than $30 \%$ will drain the charge quickly. This results in the reduction of energy density amounting to increased capital costs. They are commonly installed in uninterruptible power supply (UPS) systems as well as in renewable and distributed power systems.

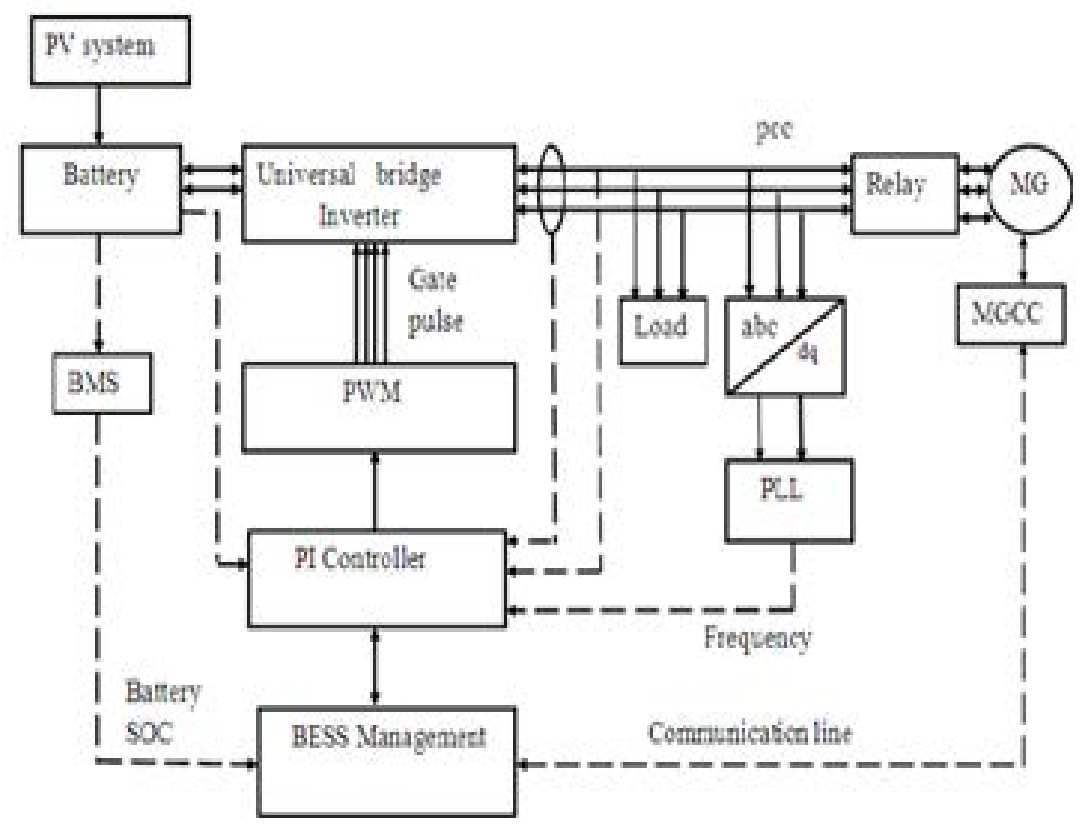

Figure 4. Structure of battery storage ${ }^{9}$. 


\subsubsection{Valve Regulated Lead Acid Battery (VRLA)}

VRLA use the same basic electrochemical technology as flooded lead-acid batteries, but these batteries are closed with a pressure regulating valve, so that they are basically sealed. The major advantages of VRLAs are less cost in maintenance and the battery cells can be packaged more tightly because of the sealed construction and immobilized electrolyte, reducing the footprint and weight of the battery $^{10}$.

\subsubsection{Lithium Ion Battery}

Lithium-ion batteries have a high energy density (energy in relation to volume) as well as power density (rate at which energy changes) compared to other batteries. This allows them to take up minimum physical space while providing high energy and power ${ }^{11}$.

\section{Microgrid System Design}

\subsection{Fuel Cell Circuit Design}

Designation of fuel cell is done by referring to the Simulink library. From the library, the design can be drag to the drawing column. Figure 5 shows the fuel cell stack. The Fuel Cell Stack block appliance a generic model parameterized correspond to most popular types of fuel cell stacks fed with hydrogen and air. The block represents two versions of the stack model: a simplified model and a detailed model. In this research, the option chooses for the stack is simplified model by switching the detail level in the block dialog box.

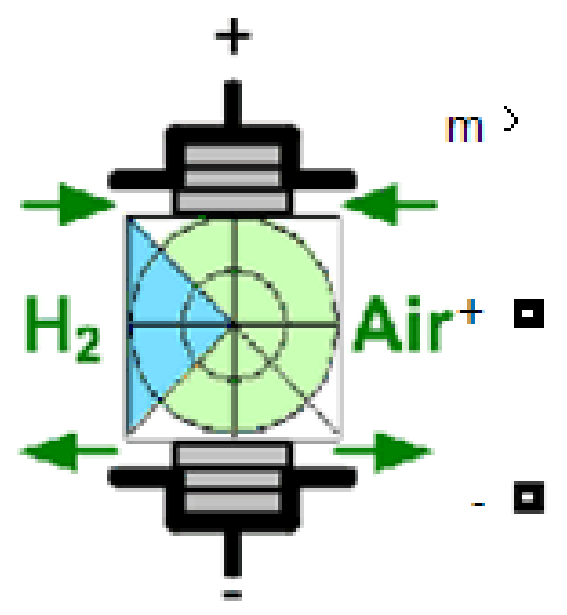

Figure 5. Fuel cell stack?

\subsubsection{Simplified Model}

In this project, the drawing for the circuit is using simplified model as shown in Figure 6. The simplified model corresponds to a particular fuel cell stack operating at nominal conditions of temperature and pressure. From the simplified circuit, the graph shows in Figure 7 can be divided into three parts which are activation region, ohmic region and mass transport region. The first region represents the activation voltage drop due to the slowness of the chemical reactions taking place at electrode surfaces. The second region represents the resistive losses due the internal resistance of the fuel cell stack. Finally, the third region represents the mass transport losses resulting from the change in concentration of reactants as the fuel is used.

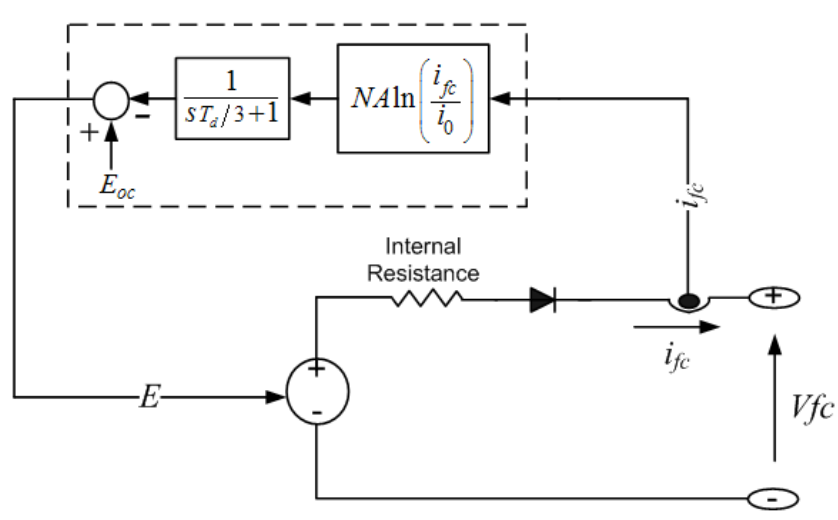

Figure 6. Simplified model.

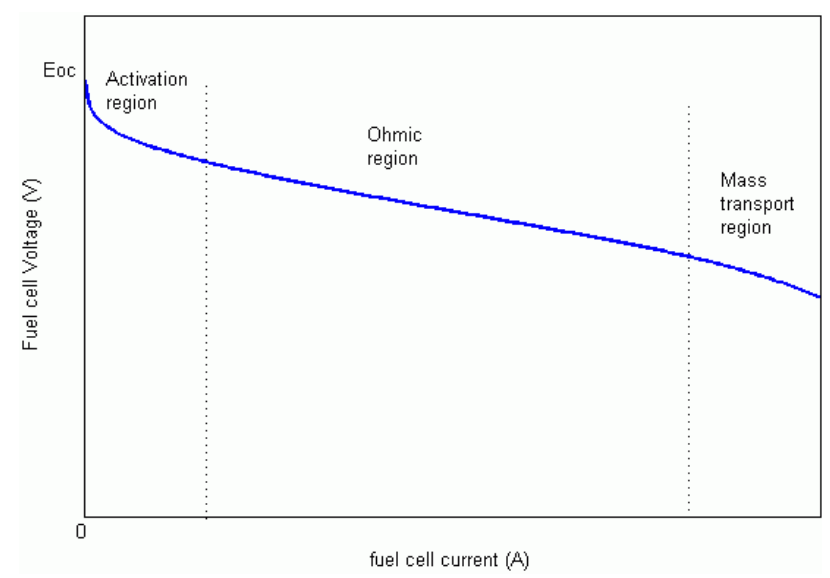

Figure 7. Fuel Cell I-V polarization curve

\subsubsection{Fuel Cell Simulink Model}

There are few types of fuel cell in the Simulink library model, in this project PEMFC is choose based on the 
characteristic value of power and dc voltage that higher than the other type. Figure 8 shows a basic circuit from the Simulink library. From the Figure 9, the parameters are set as shown. PEMFC type is chose based on the value of Vdc. It is better to have $625 \mathrm{Vdc}$ since it will experi- ence voltage drop until $415 \mathrm{Vdc}$, which is a suitable value of voltage to supply to the load. The model detail level is fixed to simplified circuit. The simplified model represents a particular fuel cell stack operating at nominal conditions of temperature and pressure. The output of fuel

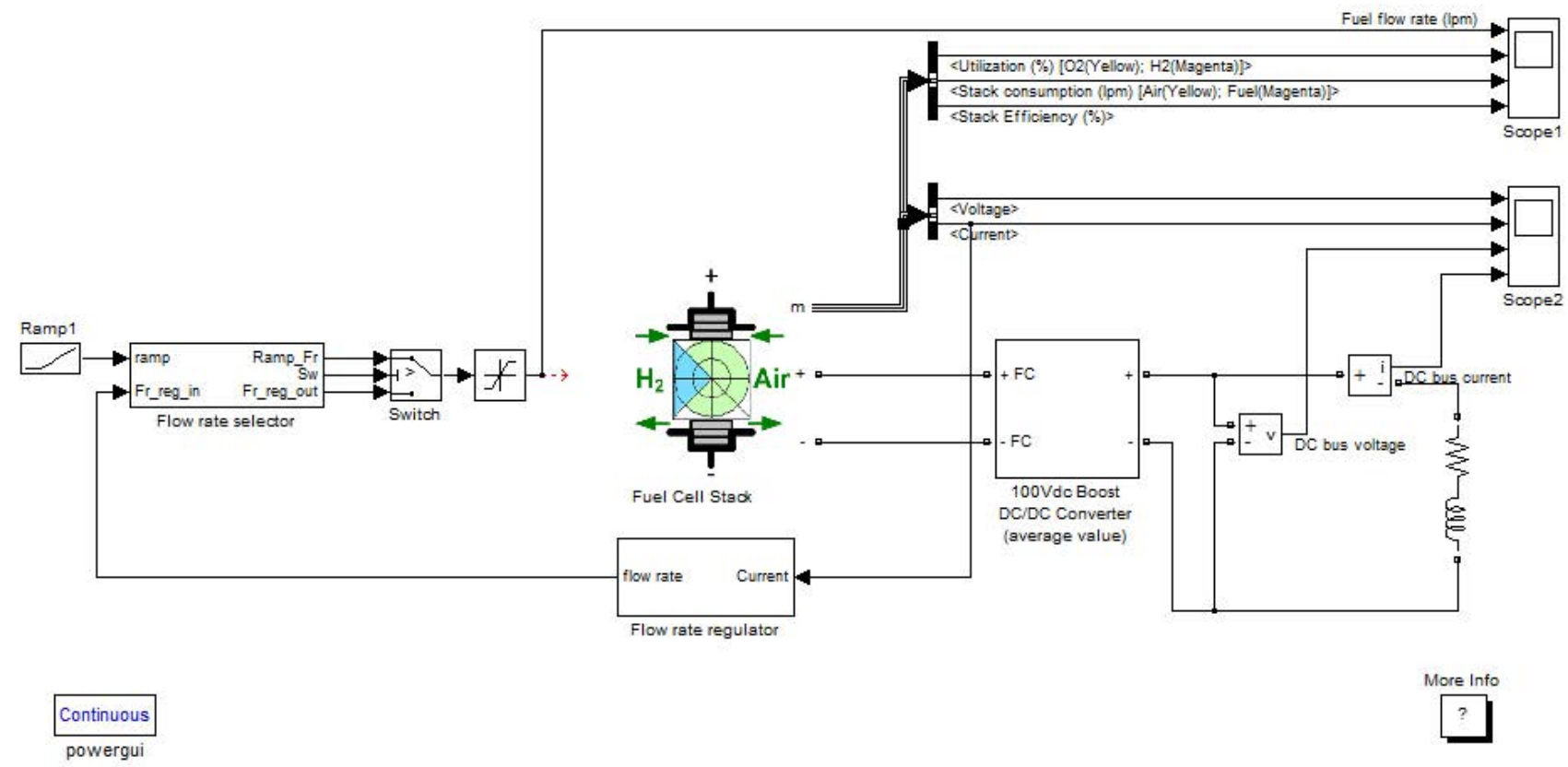

Figure 8. PEMFC 50KW 625Vdc circuit.

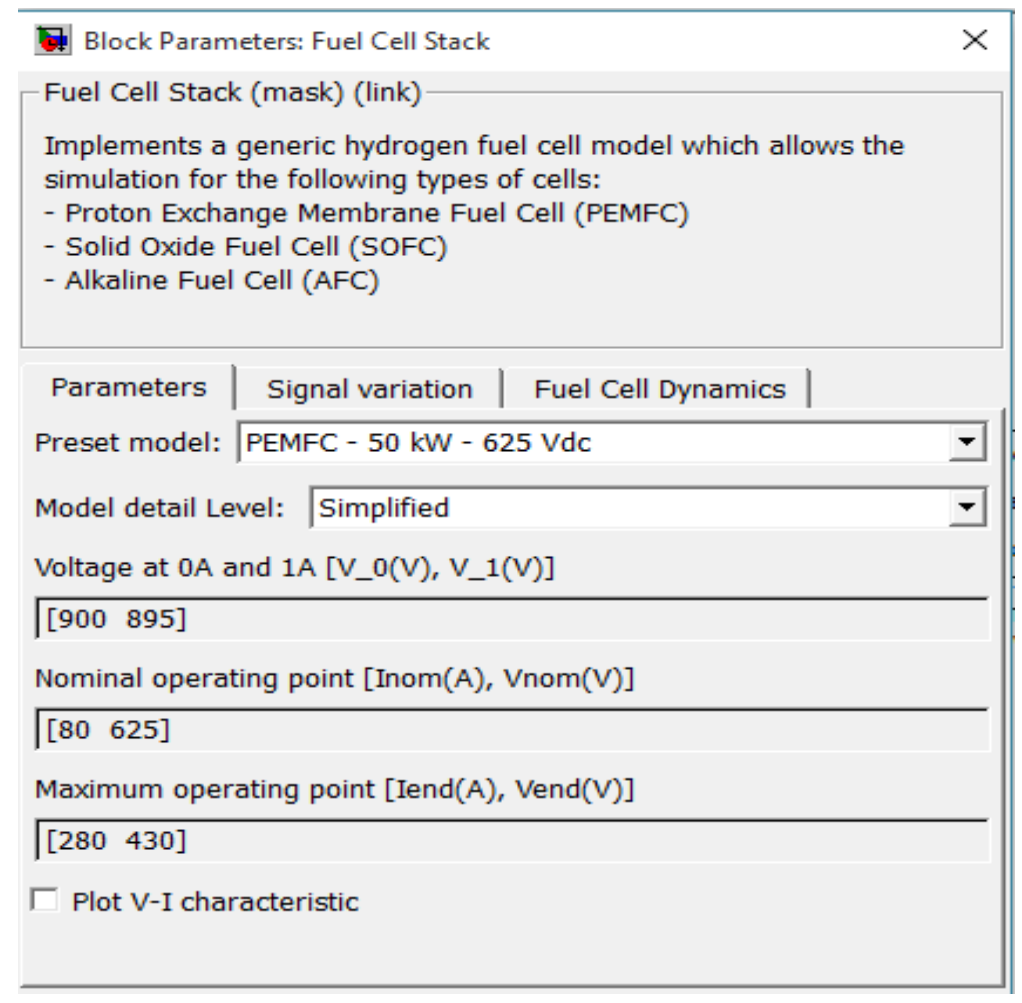

Figure 9. Block parameter for fuel cell stack. 


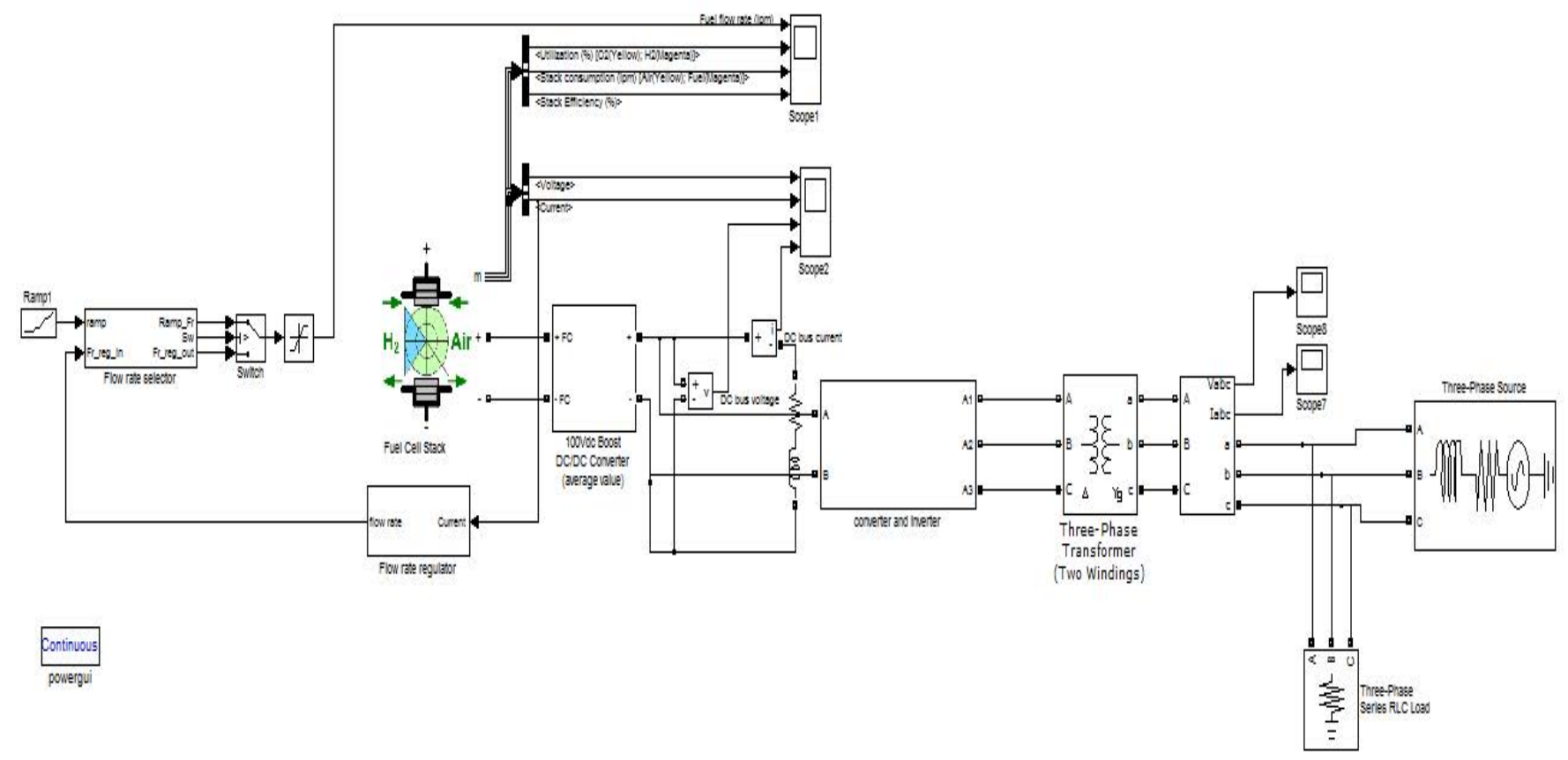

Figure 10. PEMFC circuit connected with grid.

cell is in dc so the converter and inverter is used to convert $\mathrm{dc}$ to ac. To connect the circuit with grid, transformer is used to step down the voltage from the grid to the fuel cell system. The circuit in Figure 10 shows the connection of the fuel cell with main grid.

\subsection{Battery Storage Circuit Design}

Designation of battery storage is done by referring to the Simulink library. From the library, the design can be drag to the drawing column. Figure 11 shows the battery storage stack. In this research, the type of battery storage chose is Lead-Acid based on the explanation in literature review section. Lead-Acid is the most used for uninterruptable power supply since it has bigger storage than others. Figure 12 shows the parameters of the battery storage. In this project the value of battery capacity is $50 \mathrm{Ah}$. Ah is the value for Ampere times hour which means one-amp hour is equal to one ampere of current drawn for one hour of time. The output of voltage that operate the system is $400 \mathrm{~V}$.

From Figure 13, the battery is connected to the converter and inverter to change from dc to ac. After getting the value of ac voltage and current, the value is step up using transformer to connect it with grid.

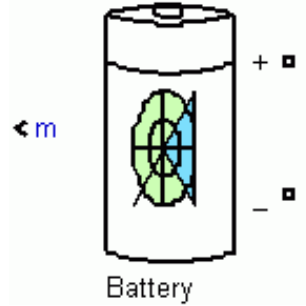

Figure 11. Battery storage stack ${ }^{11}$.

\begin{tabular}{l}
\hline Block Parameters: Battery \\
Battery (mask) (link) \\
Implements a generic battery that model most popular battery \\
types. Uncheck the "Use parameters based on Battery type and \\
nominal values" parameter to edit the discharge characteristics. \\
Parameters View Discharge Characteristics \\
Battery type Lead-Acid \\
Nominal Voltage (V) \\
400 \\
Rated Capacity (Ah) \\
50 \\
Initial State-Of-Charge (\%) \\
\hline 100 \\
$\square$ Use parameters based on Battery type and nominal values \\
\hline
\end{tabular}

Figure 12. Block parameter for battery storage. 


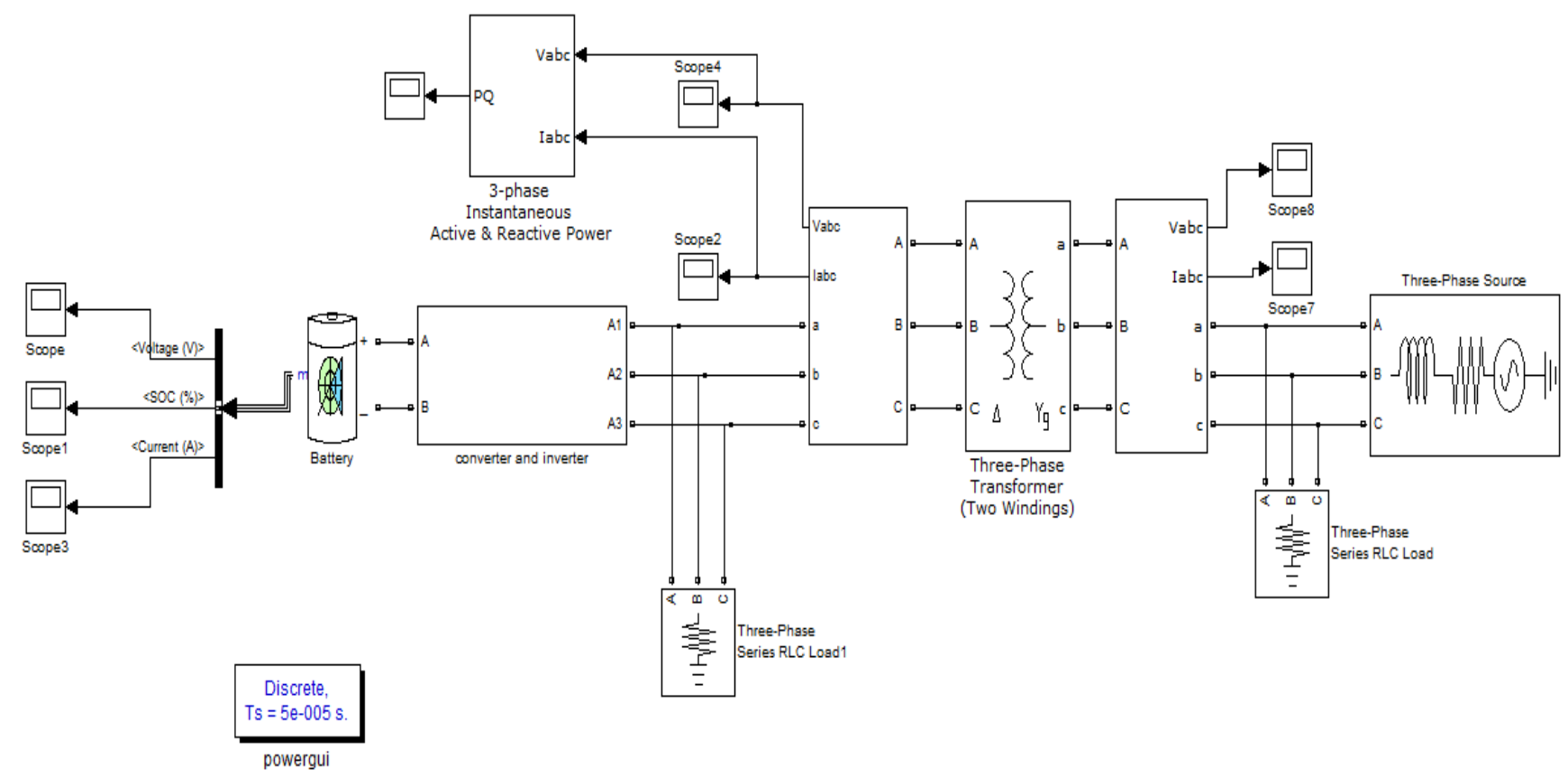

Figure 13. Battery storage circuit connected with grid.

\subsection{Microgrid System Circuit Design}

After designing fuel cell and battery storage, both plants are connected together with grid. Figure 14 has shown the connection for the microgrid. Figures 15, 16 shows a breaker is put at the grid to compare the value of voltage, current, active power and reactive power before and after opening the breaker. Opening the breaker will lead the system to be in islanded mode which is the system is operating without the power supply from the grid. In this paper, grid-connected mode is referring to the normal condition that is the supply of power is comes from grid and grid-disconnected mode is referring to the islanded mode.

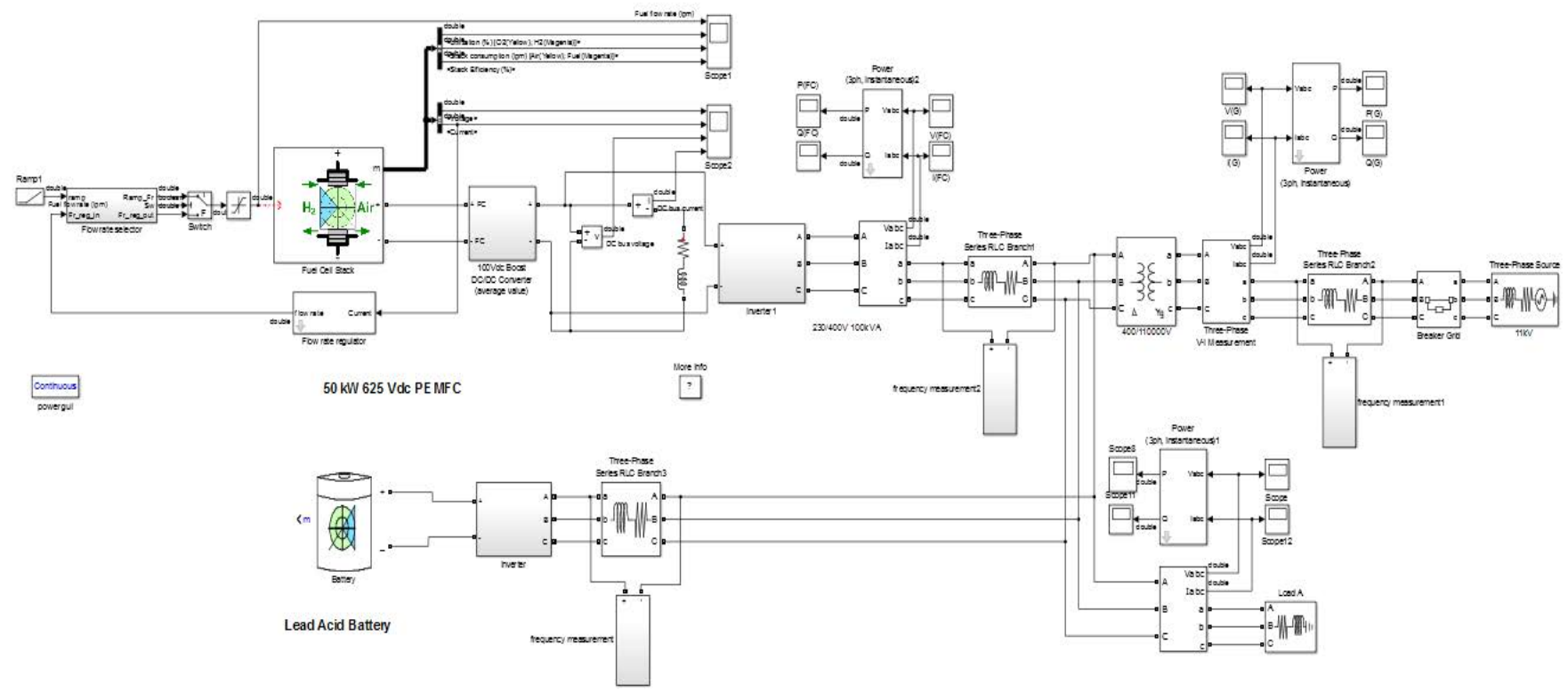

Figure 14. Microgrid system circuit design. 


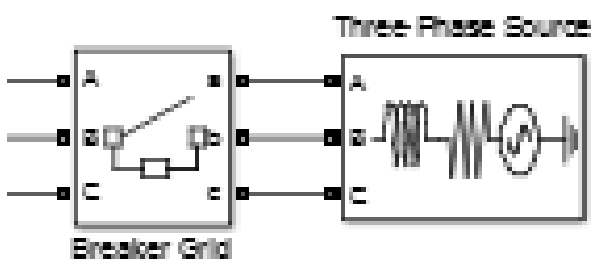

$11 \mathrm{k}$

Figure 15. Breaker connected at grid in opened mode.

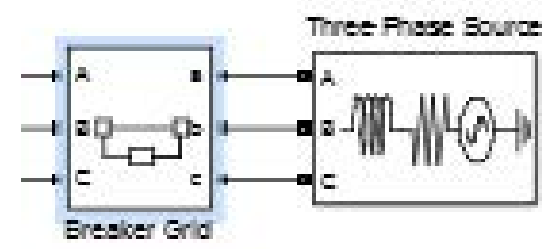

$11 \mathrm{KV}$

Figure 16. Breaker connected at grid in closed mode.

\section{Result and Discussion}

\subsection{Result of Fuel Cell}

Figure 17 shows the fuel cell voltage and current. The voltage basically starts with $625 \mathrm{~V}$ and decreased to $415 \mathrm{~V}$. This is due to the chemical reactions that take part during start up. The value of the current and voltage below are in $\mathrm{dc}$ since fuel cell is operating the system with the output of $\mathrm{dc}$. The analysis for fuel cell is done for voltage and current at the fuel cell side only since the design is in separate circuit with battery storage.

The value of $\mathrm{dc}$ is then changed to ac using inverter. Figure 18 is the result for ac voltage of fuel cell. The value from the graph is shown in Figure 19 is achieving $600 \mathrm{~V}$ this is due to the value from the dc voltage of fuel cell that is $625 \mathrm{~V}$. As a DG for three phase supply the value of the voltage is $415 \mathrm{~V}$ so the voltage is step down to $415 \mathrm{~V}$ using transformer. The value of current obtained is $25 \mathrm{~A}$ as shown in Figure 20. Both voltage and current obtained are in Vpp value.

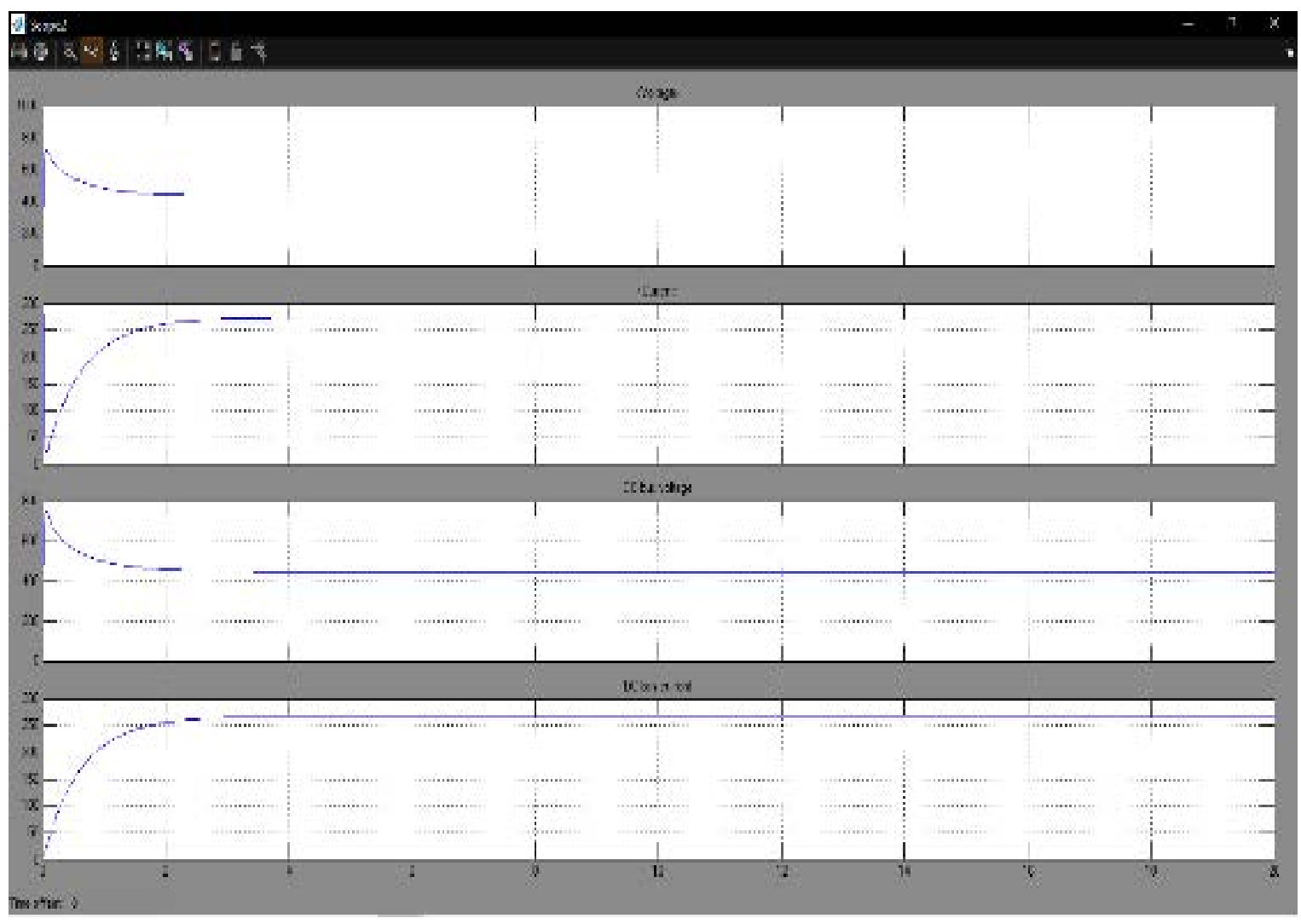

Figure 17. Voltage and current of fuel cell. 


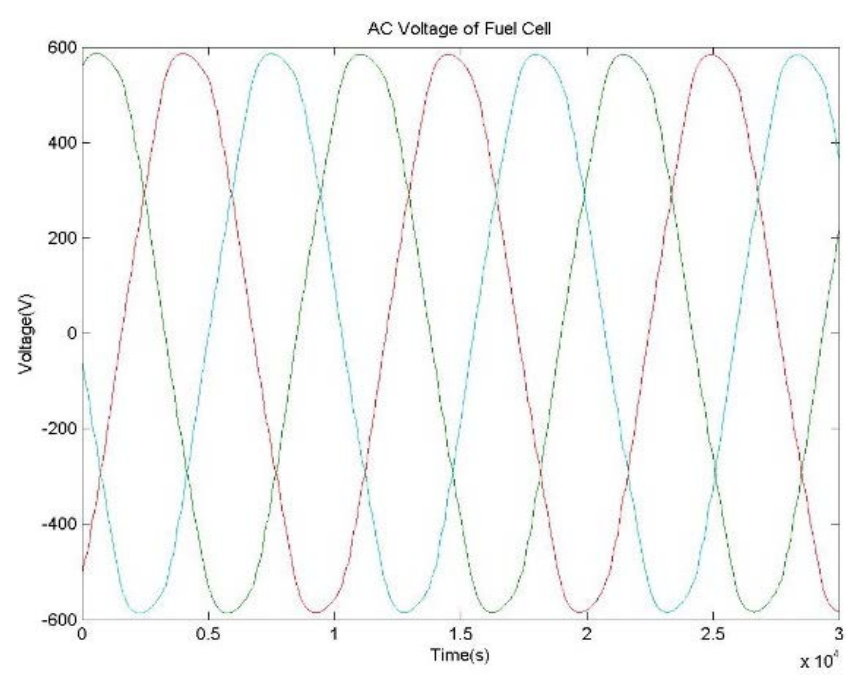

Figure 18. AC voltage of fuel cell.

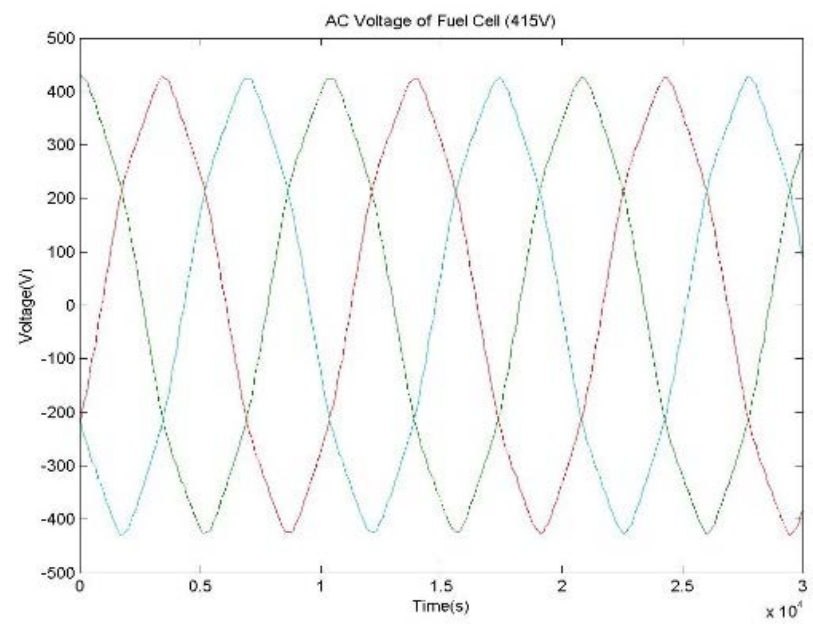

Figure 19. AC voltage of fuel cell after step down.

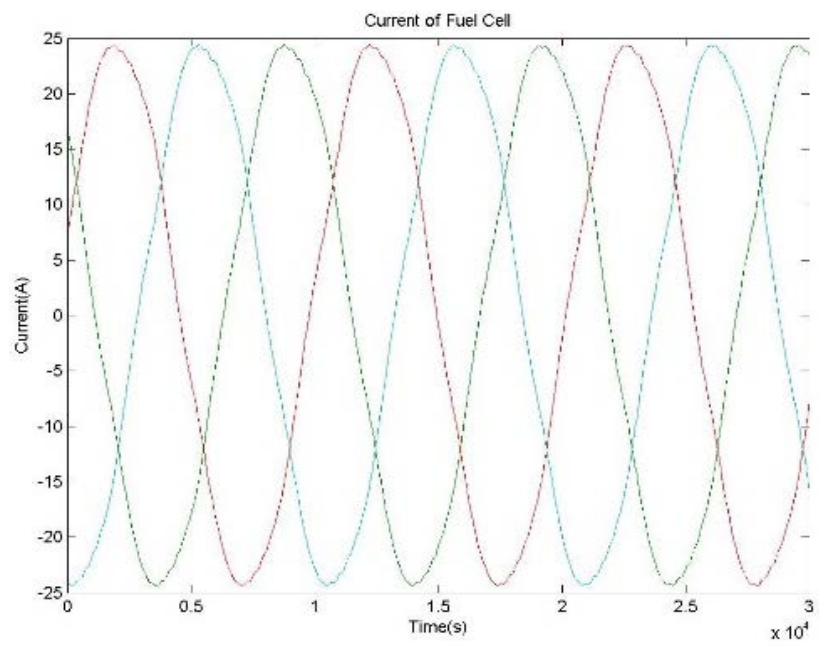

Figure 20. Current of fuel cell.

\subsection{Result of Battery Storage}

From the circuit shown in Figure 21, the analyzing of the voltage and current is observed after the inverter is connected to the battery storage. The value of voltage obtain is in phase to phase voltage, Vp-p, that is $415 \mathrm{~V}$. The analysis for battery storage is done for voltage and current at the battery storage side only since the design is in separate circuit with fuel cell.

For current, the value obtained is 15A. The value of current is also after connecting the inverter with battery as in circuit shown in Figure 22.

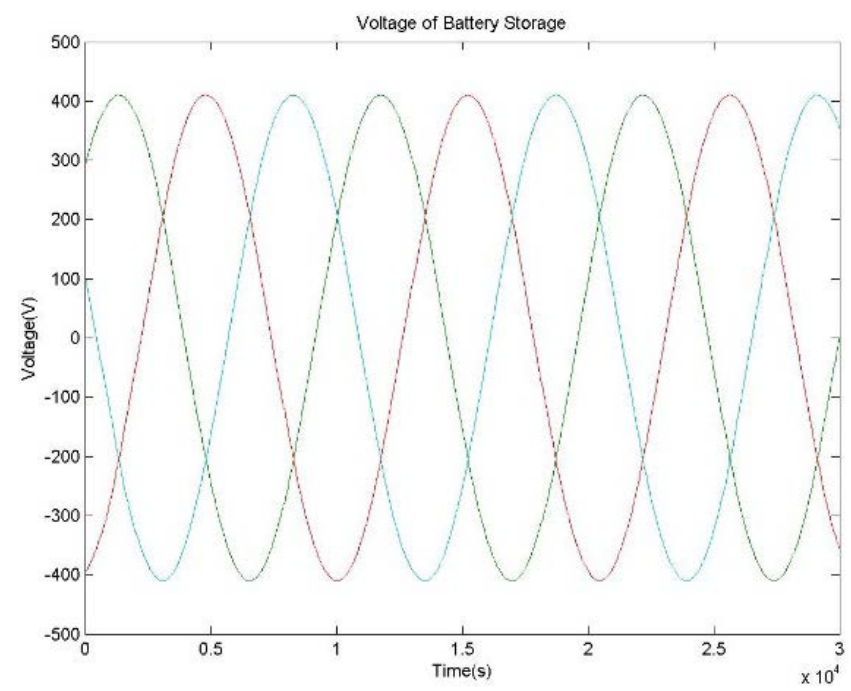

Figure 21. Voltage of battery storage.

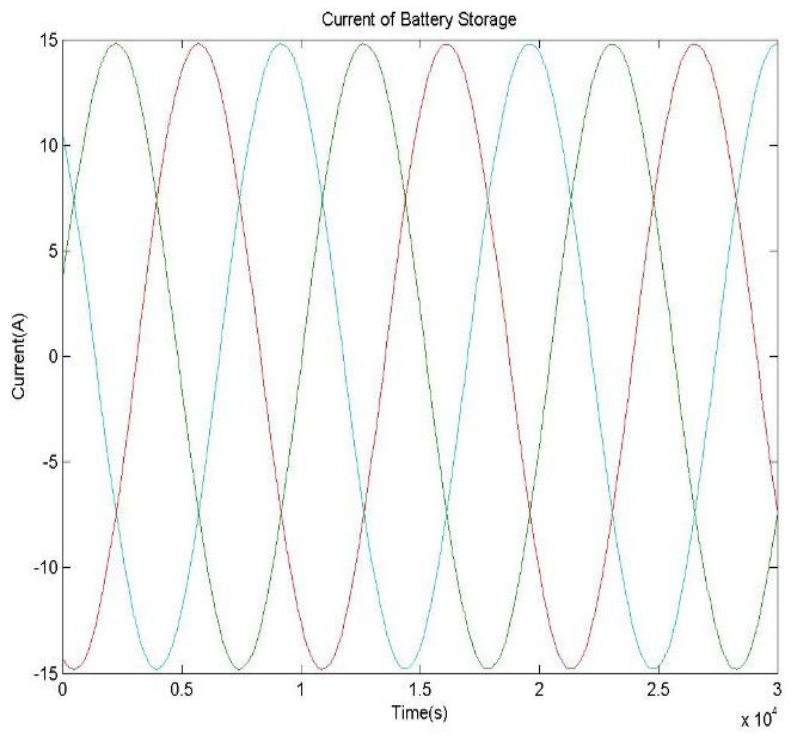

Figure 22. Current of battery storage. 


\subsection{Results of Microgrid}

To form a microgrid system, fuel cell system and battery storage are connected to a grid through a step up transformer. This microgrid system is using a breaker at the grid and the simulation is done with the breaker in closed mode and open mode. The simulation with breaker in closed mode is referring to grid - connected mode while simulation with breaker in opened mode is referring to grid - disconnected mode. The analysis will be included voltage, current, real power and reactive power.

\subsubsection{DG Results in Grid - connected Mode}

The value of voltage obtain at the DG side is $415 \mathrm{~V}$. The value obtained in Figure 23 shows the voltage from combination of fuel cell system and battery storage system. The value of current show in Figure 24 obtained is 35A and the value of active power show in Figure 25 obtained is $7000 \mathrm{~W}$.

The value of reactive power as shown in Figure 26 is -9000 Var. The value for reactive power is negative. The negative show the flowing power is from grid to DG since DG the power generates by DG is not enough.

\subsubsection{Grid Results in Grid - connected Mode}

This section showing the value of voltage, current, active power and reactive power at the grid in grid - connected mode. Figure 27 shows the voltage achieved are $11 \mathrm{kV}$. The value of current show in Figure 28 obtained is $1.4 \mathrm{~A}$ and

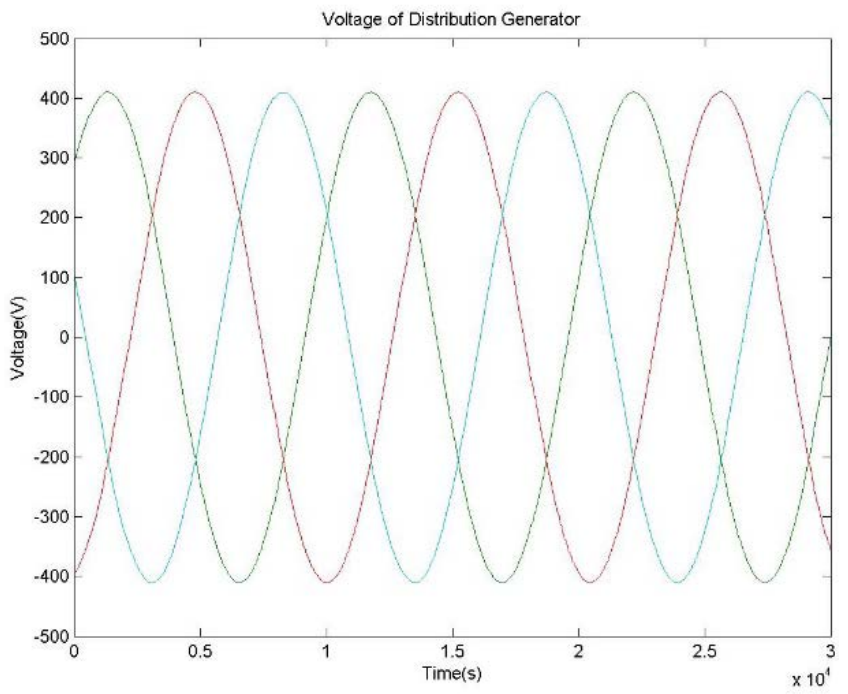

Figure 23. Voltage of DG in grid - connected mode.

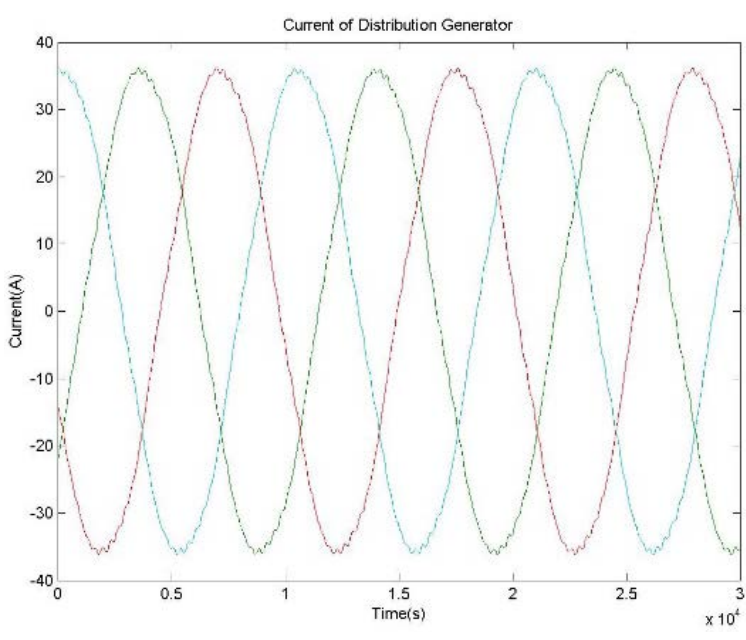

Figure 24. Current of DG in grid - connected mode.

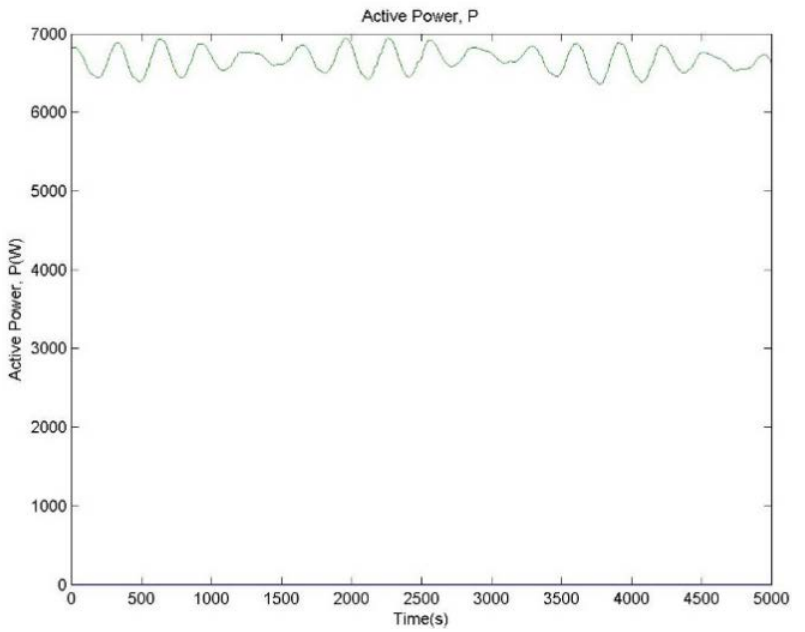

Figure 25. Active power, P of DG grid - connected mode.

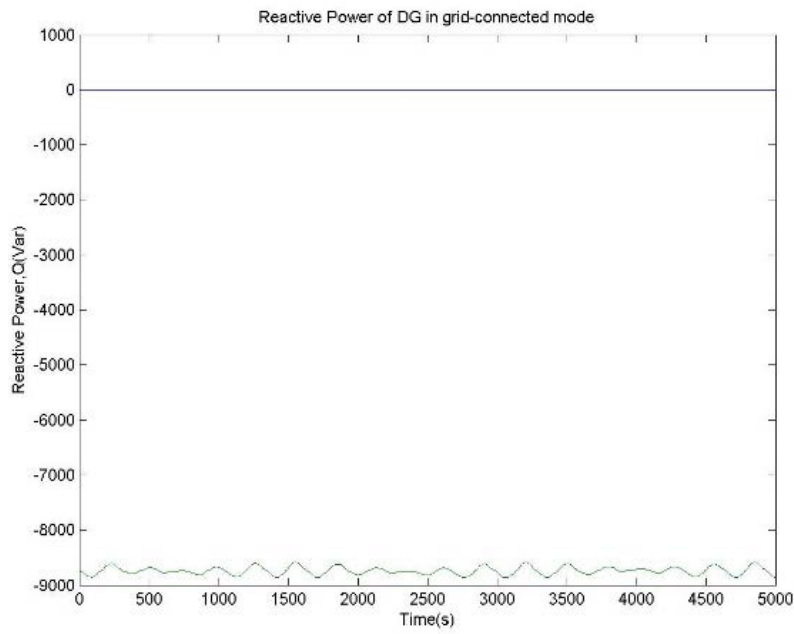

Figure 26. Reactive power, Q of DG in grid - connected mode. 


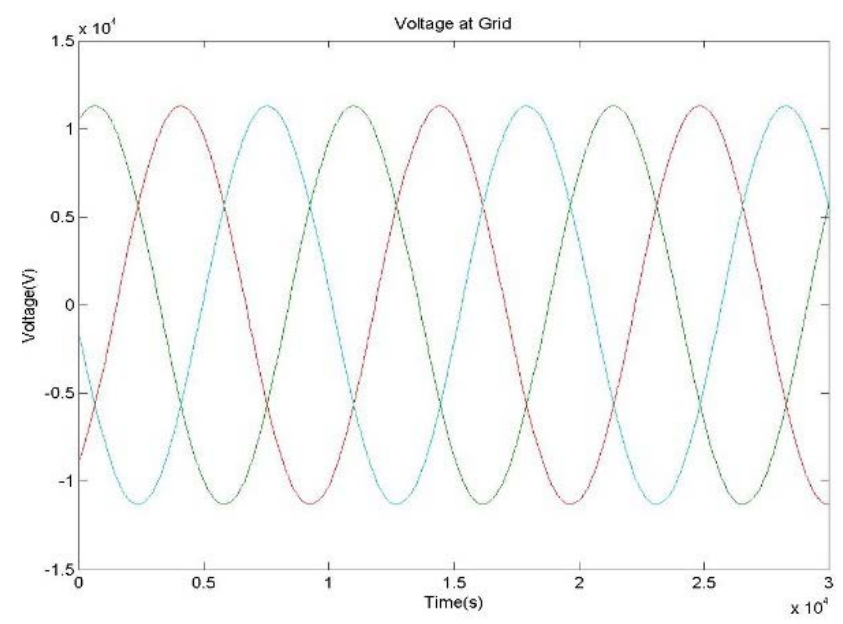

Figure 27. Voltage at grid in grid - connected mode.

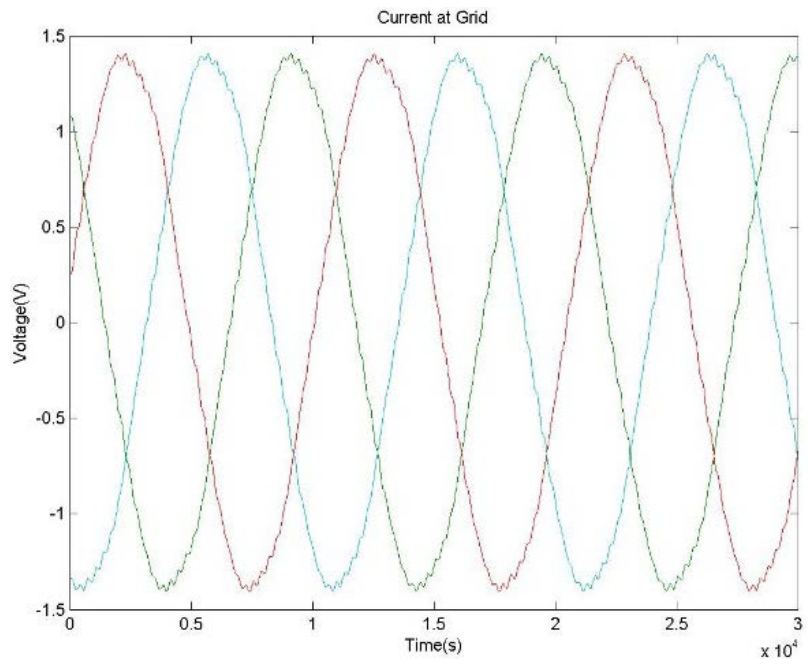

Figure 28. Current at grid in grid - connected mode.

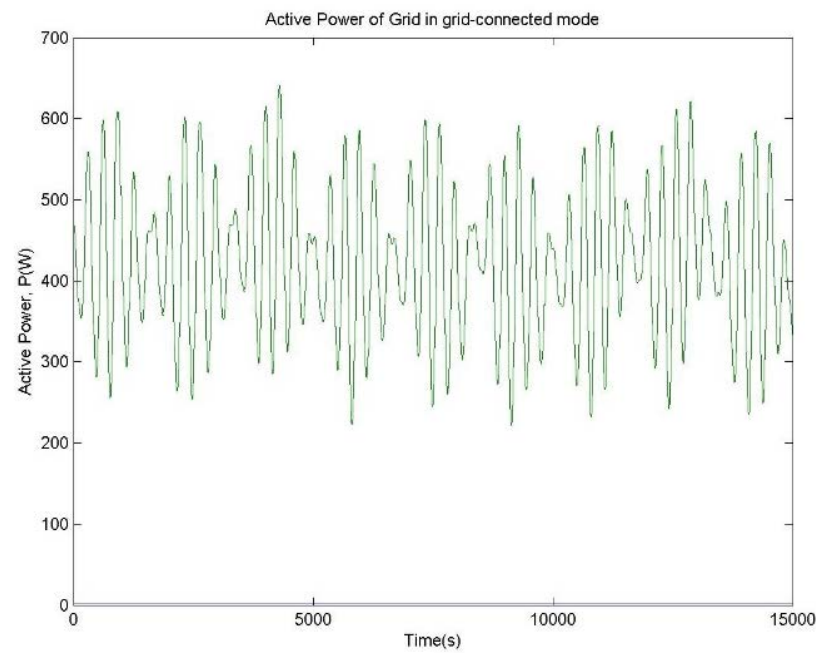

Figure 29. Active power at grid in grid - connected mode.

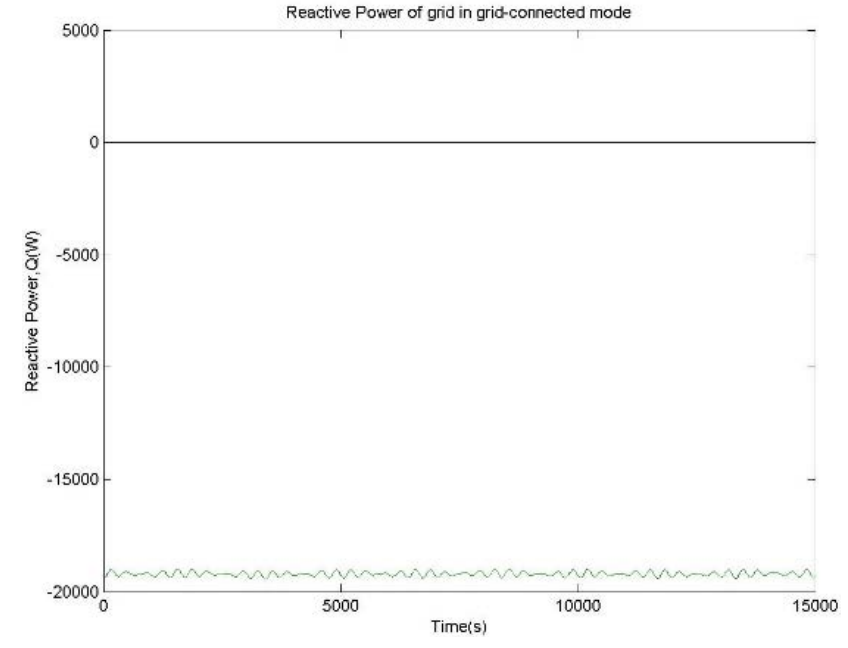

Figure 30. Reactive power at grid in grid - connected mode.

the value of active power show in Figure 29 is $600 \mathrm{~W}$. The negative from active power showing the flow of the power is flowing from DG to the grid.

The value of reactive power as shown in Figure 30 is $-18 \mathrm{kVar}$. The value of reactive power is high and in negative value since the value of active power is low and the generating power is not enough hence the negative value shows the draw of power from DG to the grid.

\subsubsection{DG Results in Grid - disconnected Mode}

This section shows the results obtained when the simulation is run in grid - connected mode that is when opening the breaker at the grid. From Figure 31, the voltage

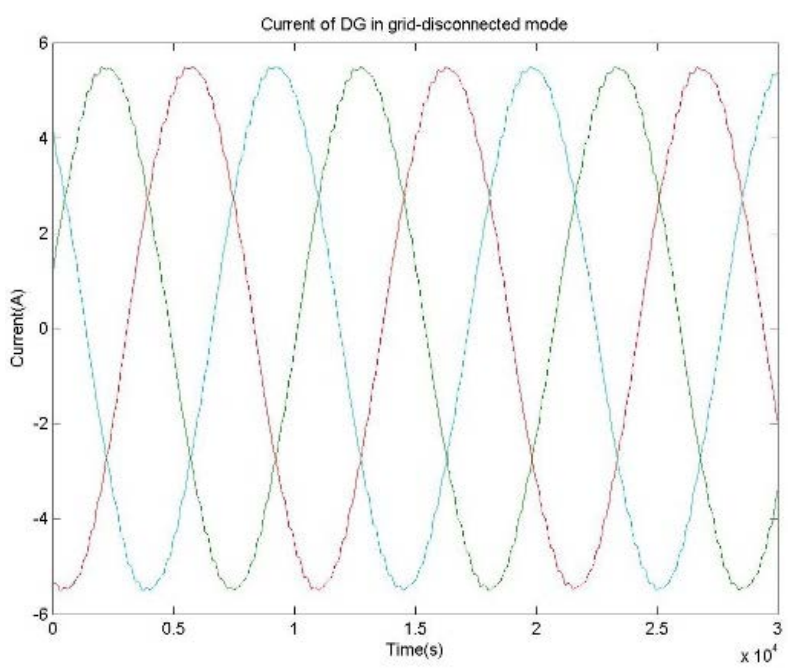

Figure 32. Current of DG in grid - disconnected mode. 


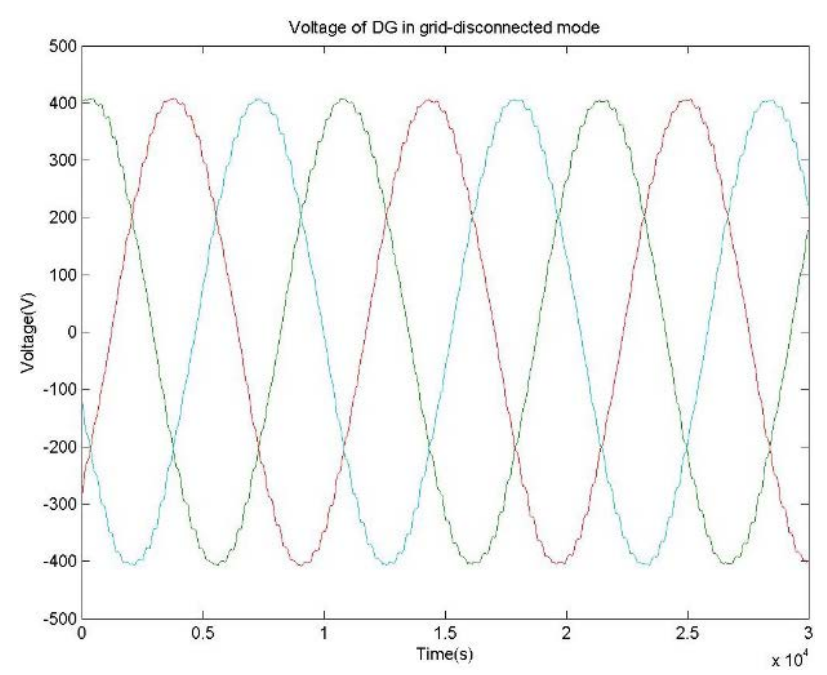

Figure 31. Voltage of DG in grid - disconnected mode.

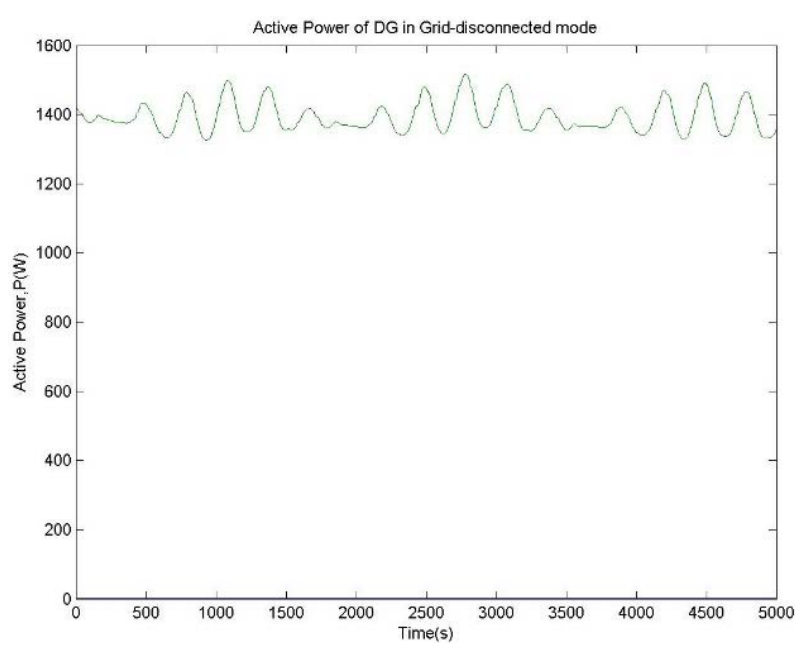

Figure 33. Active power of DG in grid - disconnected mode.

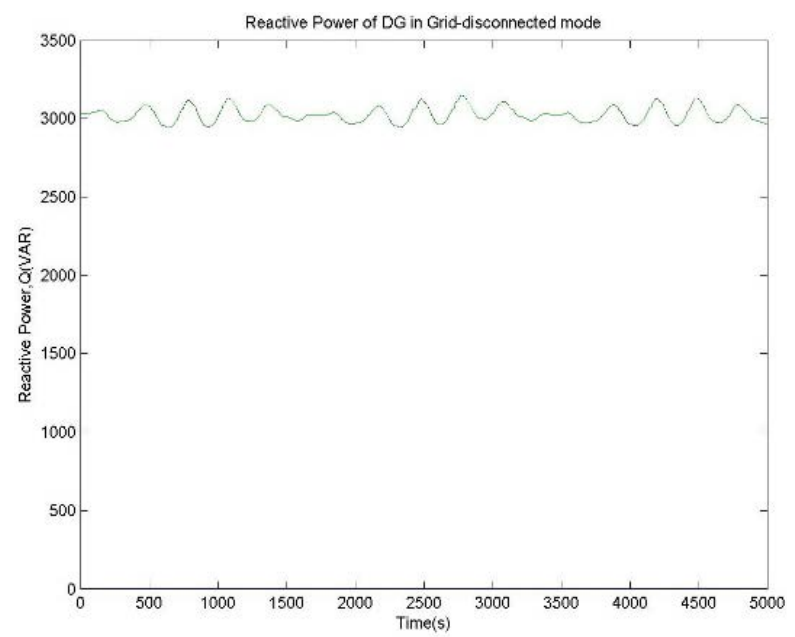

Figure 34. Reactive power of DG in grid - disconnected mode. obtained at DG side is $415 \mathrm{~V}$. The value of current show in Figure 32 obtained is $5 \mathrm{~A}$.

The value obtained for active power show in Figure 33 in DG connected in grid - disconnected mode is $1400 \mathrm{~W}$. The negative value showing the flow of the power from the grid to the DG. The value of reactive power show in Figure 34 of DG in grid - disconnected mode is 3000 Var.

\subsubsection{Grid Results in Grid - disconnected Mode}

This section showing the results obtained at the grid side when running the simulation in grid - disconnected mode which is opening the breaker. The voltage shows in Figure 35 obtained is $6000 \mathrm{~V}$ lower than $11 \mathrm{kV}$ as obtained in grid - connected mode. The value of current show in

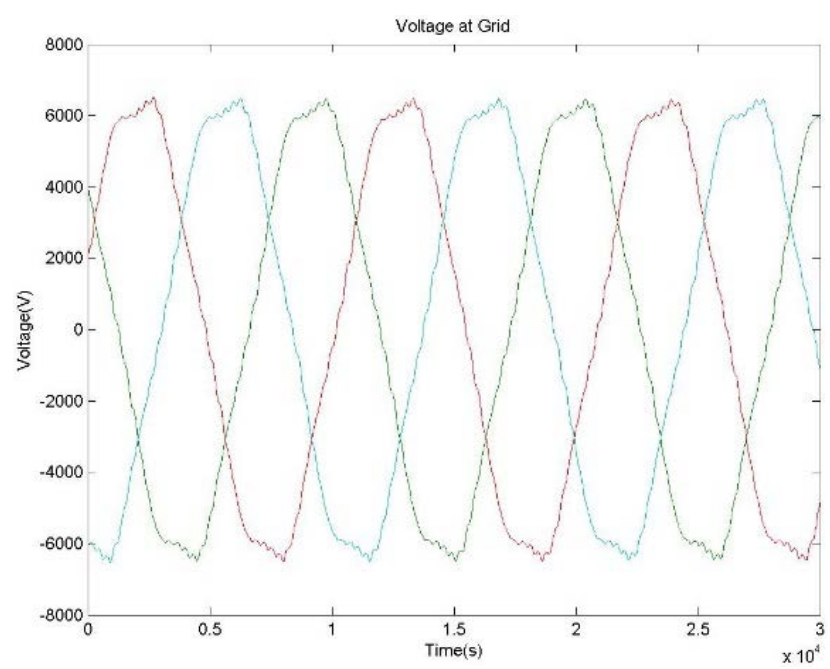

Figure 35. Voltage of grid in grid - disconnected mode.

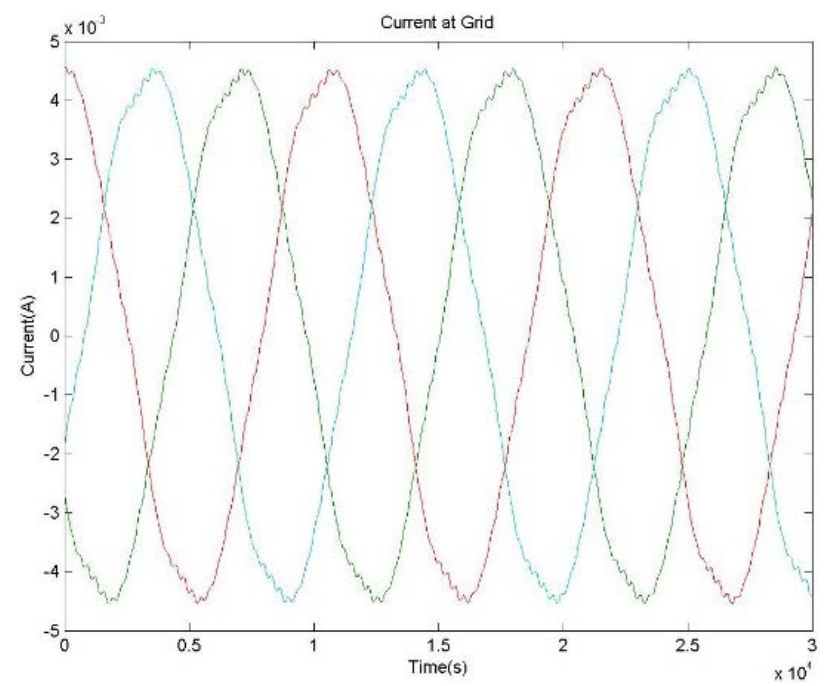

Figure 36. Current at grid in grid - disconnected mode. 
Figure 36 is $4.5 \mathrm{~mA}$ and the value of active power show in Figure 37 obtained is $14 \mathrm{~W}$.

The value obtained for the reactive power as shown in Figure 38 is -40 Var. The value is in negative since it has no supply to generate the power itself, so the power is draw from the DG.

\subsection{Analysis between the Grid - connected Mode and Grid - disconnected Mode}

From the Table 1, the voltage value when closed the breaker is normal at $415 \mathrm{~V}$ in $\mathrm{DG}$ and $11 \mathrm{kV}$ in grid. However, the value of voltage at grid is low, reduced to $6000 \mathrm{~V}$. The value of DG in grid-connected mode is main-

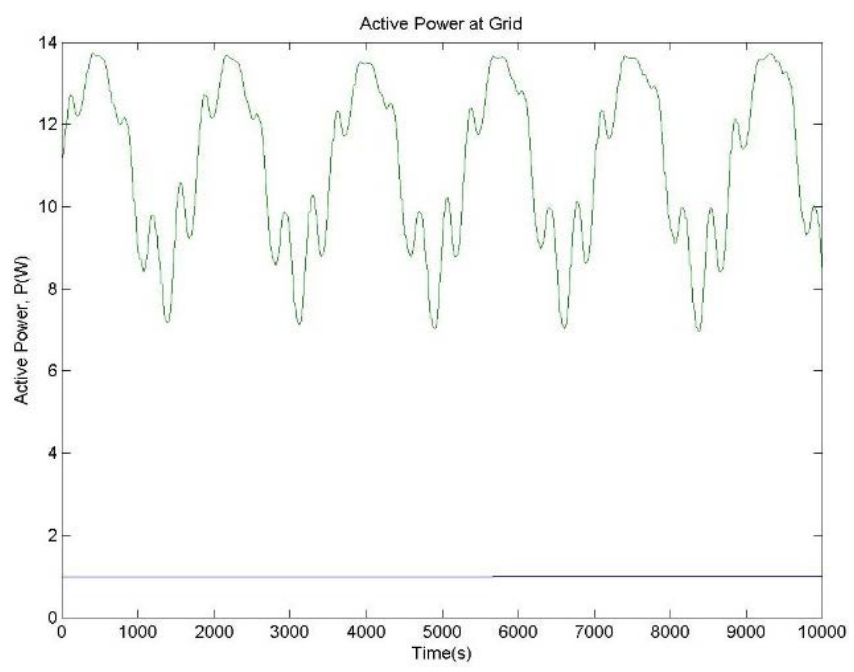

Figure 37. Active power at grid in grid - disconnected mode.

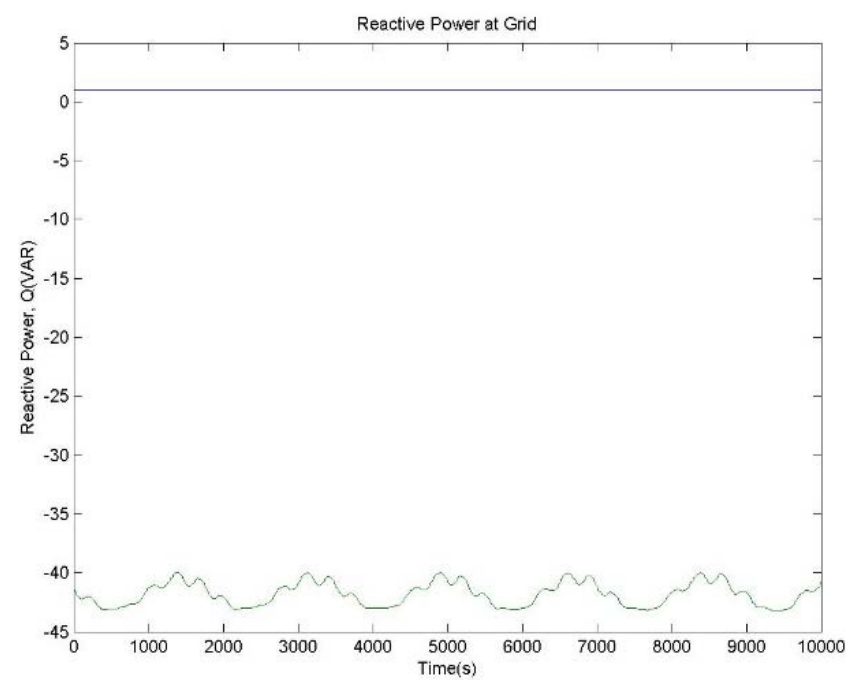

Figure 38. Reactive power at grid. tained as in grid-connected mode since it has to stay generating in stand - alone system. The value of current also reduced from $35 \mathrm{~A}$ to $5 \mathrm{~A}$ in $\mathrm{DG}$ and $5 \mathrm{~A}$ to $4.5 \mathrm{~mA}$ in grid source since the source is no longer supplying the power. The value of both power, active and reactive for the DG in grid - connected mode are in positive value shows that the direction of the flowing power is from grid to the generator. Even when in grid-disconnected mode, the value is still positive since it operates in stand - alone. The situation is different from grid source; the value of reactive power is both in negative shows the flowing of power is from DG to the grid.

Table 1. Comparison between opened breaker and closed breaker

\begin{tabular}{|l|l|l|l|}
\hline \multirow{4}{*}{ System } & \multirow{2}{*}{ Parameters } & \multicolumn{2}{|l|}{$\begin{array}{l}\text { Condition of } \\
\text { Breaker }\end{array}$} \\
\cline { 2 - 4 } & & Closed & Opened \\
\hline \multirow{4}{*}{$\begin{array}{l}\text { Distribution } \\
\text { Generator(DG) }\end{array}$} & Voltage(V) & 415 & 415 \\
\cline { 2 - 4 } & Current(A) & 35 & 5 \\
\cline { 2 - 4 } & Active Power, P(W) & 4300 & 3000 \\
\cline { 2 - 4 } & $\begin{array}{l}\text { Reactive Power, } \\
\text { Q(VAR) }\end{array}$ & 25000 & 1500 \\
\hline \multirow{5}{*}{ Grid Source } & Voltage(V) & 11000 & 6000 \\
\cline { 2 - 4 } & Current(A) & 5 & $4.5 \times 10^{-3}$ \\
\cline { 2 - 4 } & Active Power, P(W) & 600 & 14 \\
\cline { 2 - 4 } & $\begin{array}{l}\text { Reactive Power, } \\
\text { Q(VAR) }\end{array}$ & -18000 & -40 \\
\hline
\end{tabular}

\section{Conclusion}

From studying the operation of DG, MG and battery storage in the system network, it would be best to have microgrid system implemented in small area like hospital to have continuous power supply without interruption. All the circuit of fuel cell, battery storage and MG system are successfully design by using MATLAB Simulink software. By analyzing the performance of fuel cell and battery storage system of microgrid by using MATLAB Simulink Software, it shows that the performance of the system is reduced in grid-disconnected mode than in grid-connected mode. In addition, I would recommend the MG system to be improved by implement control system. Other than that is the DG system is not only limited to two types of DG in one MG system, it can be more than two so the MG system can be improved by adding different type of DG or substitute fuel cell with another type of DG. 


\section{Acknowledgement}

We wish to express our gratitude to Universiti Teknikal Malaysia Melaka (UTeM) especially for Faculty of Electrical Engineering from UTeM to give the financial budget as well as moral support for complete this project successfully.

\section{References}

1. Malhotra DP. Modelling and simulation of fuel cell based dc microgrid; 2014. p. 1-51.

2. Ahmed M, Amin U, Aftab S, Ahmed Z. Integration of renewable energy resources in microgrid. Energy and Power Engineering. 2015; 7(1):12-29. https://doi.org/10.4236/ epe.2015.71002

3. Chowdhury R, Boruah T. Design of a microgrid system in Matlab/Simulink. International Journal of Innovative Research in Science, Engineering and Technology. 2015; 4(7):1-8.

4. Singh A, Surjan BS. Microgrid: A review. International Journal of Research in Engineering and Technology. 2014; 3(2):1-14.
5. Krishna SV, Suman T. A new PV/fuel cell based bidirectional converter for microgrid applications. International Journal of Emerging Engineering Research and Technology. 2014; 2(5):121-9.

6. Jaim R, Singh D, Kumar V. Design and modeling of fuel cell using Matlab Simulink. 2015; 2(8):19-22

7. Feroldi D, Basualdo M. Description of PEM fuel cells system. Springer-Verlag London Limited; 2012. p. 1-25. https://doi.org/10.1007/978-1-84996-184-4_2

8. Bahmani-Firouzi B. Optimal sizing of battery energy storage for microgrid operation management using a new improved Bat Algorithm. Electrical Power and Energy Systems. 2014; 56:42-54. https://doi.org/10.1016/j.ijepes.2013.10.019

9. Aravindan P, Subbulakshmi G. Uninterrupted supply and frequency support for local load in Microgrid by Battery Energy Storage System (BESS). International Journal of Advanced Research in Electrical, Electronics and Instrumentation Engineering. 2015; 4(2):1-7.

10. Joseph A, Shahidehpour M. Battery storage systems in electric power systems. IEEE Power Engineering Society General Meeting; 2006. p. 1-8. https://doi.org/10.1109/ PES.2006.1709235

11. Wu G, Sun H, Pan L. Lithium-ion battery. BYD Co Ltd Shenzhen BYD Auto R\&D Co Ltd; 2014. 